\title{
Private Equity Valuation Before and After ASC 820
}

July 2018

\begin{abstract}
We examine the effect of ASC 820 (formerly known as SFAS 157) on the valuations reported by U.S. private equity funds to their investors. In 2008, the FASB implemented ASC 820 to achieve more consistent measurement and increased transparency in fair value reporting. This new standard clarified the most critical accounting policy for private equity funds, which typically include highly illiquid investments. Exploiting a setting where we can observe all cash flows over a fund's lifetime, we show that the interim reported net asset valuations (NAVs) of liquidated private equity funds more accurately predict future net distributions to investors following ASC 820 adoption, particularly for venture funds. We supplement our findings with a difference-in-difference test and numerous robustness checks. Our findings shed light on financial reporting in an opaque industry and suggest that enhanced guidance for the implementation of fair value accounting in ASC 820 improved the information environment in a significant cross-section of the financial markets.
\end{abstract}

JEL Codes: G1, G10, G30, M4, M41 


\section{Private Equity Valuation Before and After ASC 820}

\section{INTRODUCTION}

We examine the reported valuations of private equity funds during a sample period that includes the adoption of ASC 820, Fair Value Measurements (formerly known as SFAS 157). Due to diversity and inconsistency in fair value reporting, the FASB implemented ASC 820 in 2008. ${ }^{1}$ ASC 820 clarified the definition and measurement of fair values, resulting in a change to the most important accounting policy for private equity funds. Yet, we know very little about financial reporting in this large and growing sector. Recent SEC inquiries of several private equity firms (Lattman 2012; Maremont and Spector 2014) highlight the importance of valuation and reporting in the private equity industry. Moreover, according to a recent survey by Preqin, 88 percent of limited partners consider valuation to be the greatest issue in the private equity industry. ${ }^{2}$ Our focus on reported valuations and fair value measurement by private equity funds allows us to capitalize on a setting that differs from other investment classes insomuch as the underlying investments are highly illiquid and we can observe all cash flows to and from investors over a fund's lifetime, negating the need for terminal value estimates.

Investment in private equity continues to grow, reaching $\$ 2.83$ trillion in the U.S. in 2017, according to Preqin. With significant dollars at stake, relevant and reliable financial reporting offers private equity investors (i.e., limited partners) the ability to monitor and compare fund performance, make asset allocation decisions, and report quarterly performance information to their own investors. Moreover, private equity financial reporting has a spillover effect. Under the ASC 820 practical expedient, limited partners, including pension funds, mutual funds, and

\footnotetext{
${ }^{1} \mathrm{http}: / / \mathrm{www}$. fasb.org/summary/stsum157.shtml

${ }^{2}$ Preqin is a data provider for the alternative assets industry, and our primary data source. Survey results are summarized in http://docs.preqin.com/reports/2018-Preqin-Global-Private-Equity-Report-Sample-Pages.pdf
} 
endowments, generally incorporate the fair value provided by the fund in their own financial statements. ${ }^{3,4}$ As a result, private equity financial reporting potentially affects the financial reporting and asset allocation decisions of private equity funds, limited partners, and their investors.

We focus on fair value accounting at the private equity fund-level and its relation to future cash flows for several reasons. Fund-level valuations are used by limited partners when making asset allocation decisions and, as mentioned above, they are the reported values that limited partners use in their own financial statements. In addition, most limited partners hold private equity investments until maturity and thus are most interested in the future cash return. ${ }^{5}$

We examine the quarterly net asset valuations (NAVs) reported by private equity funds both before and after the adoption of ASC 820. At any given point in a fund's life, the fund's NAV represents the sum of its cash contributions, or calls, to date less any distributions of realized returns to date, plus accounting recognition of unrealized returns made on investments within the fund, net of fees. Prior to ASC 820, U.S. GAAP defined fair value as "the amount at which an investment could be exchanged in a current transaction between willing parties, other than in a forced or liquidation sale" but provided little or no guidance in estimating fair values. While industry practice pre- 820 focused on estimating fair value using an entry price, ASC 820

\footnotetext{
${ }^{3}$ According to Private Equity International (2015), top private equity investors include Canada Pension Plan Investment Board (CPPIB), Washington State Investment Board (WSIB), California Public Employees' Retirement System (CalPERS), Goldman Sachs Asset Management, and Teacher Retirement System of Texas.

${ }^{4}$ ASU 2009-12 amended ASC 820 to allow reporting entities, as a practical expedient, to estimate the fair value of investments within the scope of ASU 2009-12 using the net asset value provided to them. Investments within the scope of ASU 2009-12 (often referred to as alternative investments) are commonly in the form of limited partnership interests and include investments in venture capital, private equity, and hedge funds.

${ }^{5}$ The secondary market for private equity limited partnership interests only comprises about $2-7 \%$ of the total supply of U.S. and European fund interests for the time period 2001-2013 (Capital Dynamics 2014).
} 
provides direction on how private equity funds should fair-value investments in their portfolio and requires fair values based on an exit price. ${ }^{6}$

Why is the use of fair value accounting important for the private equity industry?

Because private equity funds are almost entirely comprised of fair-valued financial instruments, consistent and reliable fair value measurements facilitate capital allocation. In addition, reports of interim performance, specifically the fair-valued NAV, prove extremely important as other publicly available benchmarks or indicators of performance are largely unavailable in this opaque market. However, the new standard's market-based approach may prove problematic in valuing private equity investments, which are generally highly illiquid with non-transparent market prices (which leads to Level 3 estimates under the ASC 820 fair value hierarchy). ${ }^{7}$ Indeed, the new standard was met with some skepticism in the private equity industry given the difficulties and costs in implementation for investments that are typically highly illiquid (Kreutzer 2009; Mendelson 2009; Rossa 2009).

Fair value accounting has been examined in other contexts in the accounting literature. Several studies explore differences across underlying asset types (Levels 1, 2, and 3) in value relevance (Song, Thomas, and Yi 2010; Lawrence, Siriviriyakul, and Sloan 2016), information risk (Riedl and Serafeim 2011), and representational faithfulness (Altamuro and Zhang 2013). Within the context of private equity, the finance literature has examined private equity performance (e.g., Kaplan and Schoar 2005), but few studies explore the reporting of

\footnotetext{
${ }^{6}$ Fair values based on entry price and exit price are not synonymous. Entry price reflects the cost to purchase, or enter into, an interest in a private equity fund. Practically speaking, this would (and did) result in limited partners valuing investments at their cost to enter into the fund, or at the price of the latest round of financing (i.e., the cost for others to enter into the fund). Exit price refers to the amount the limited partner would receive should it sell (or exit) its investment in the private equity fund.

${ }^{7}$ For example, a private equity fund might need to provide a valuation estimate of an investment in Uber or SpaceX. Under ASC 820, the fair value hierarchy includes three levels. Level 1 valuations are based on observable, independent market data and Level 2 on observable prices from similar markets. Level 3 valuations are based on unobservable data such as a pricing model or a proprietary financial forecast.
} 
performance or the use of accounting in this opaque industry. Some evidence demonstrates that managerial incentives related to fundraising for subsequent funds lead to the manipulation of reported private equity NAVs (e.g., Barber and Yasuda 2017; Brown, Gredil, and Kaplan 2017). At the same time, higher quality legal and accounting systems may constrain overvaluation (Cumming and Walz 2009).

Two studies address fair value accounting standards and private equity returns. Welch and Stubben (2018) find increased co-movement between reported private equity returns and market returns following the implementation of IAS 39 in an international setting while Brown et al. (2017) report a decrease in return autocorrelation for venture funds following ASC 820. A working paper by Jenkinson, Landsman, Rountree, and Soonawalla (2016) provides some evidence on the reliability of reported NAVs as predictors of future net distributions, but does not address fair value accounting requirements. More recently, Crain and Law (2017) explore the valuations of private companies held by private equity funds before and after fair value accounting rule changes. Our analysis differs insomuch as we explore the effect of ASC 820 on fund-level valuations (NAVs) that are provided by private equity funds and the future cash flows, net of fees, to and from the limited partners of the fund. This level of analysis is most relevant to the limited partners because they are ultimately interested in, and incorporate into their own financial statements, the performance of the fund as a whole rather than the valuation of the companies held by the funds.

Using over 13 years of quarterly NAVs, cash contributions, and cash distributions for private equity funds from Preqin's Private Equity Cash Flow Download, we form a sample of liquidated private equity funds where we can observe cash calls (contributions) and distributions 
over the lifetime of the fund. ${ }^{8}$ First, we investigate changes to NAV estimates that are not explained by distributions from or contributions to the fund (what we call valuation adjustments) in the period surrounding ASC 820 adoption. We find that, following ASC 820 adoption, private equity funds make more frequent upward valuation adjustments to their quarterly reported NAVs.

Second, we investigate the mapping between the reported NAV for the fund and the present value of net ex post distributions/contributions to/from limited partners. Our primary discount rate is the internal rate of return (IRR) ultimately realized by the fund from inception to liquidation, and our results are robust to using several other discount rates. In other words, we compare the fund's quarterly reported NAV with its net present value (NPV), i.e., the discounted net distributions to limited partners based on perfect foresight. Analogous to the studies of analysts' forecasts of earnings (e.g., Fried and Givoly 1982), we calculate a measure of the accuracy (i.e., unsigned error) and bias (i.e., signed error) of the quarterly reported NAV of the fund based on the difference between the NAV and the NPV for the quarter of the report.

We find that private equity NAVs estimate future, realized net distributions with greater accuracy following ASC 820 implementation. We also find some cross-sectional evidence of a more significant increase in accuracy for venture funds, which appears to be driven by a decrease in bias for these funds following ASC 820. Within the private equity industry, ASC 820 received the most criticism from venture capitalists as venture investments represent the most illiquid and difficult to value private equity investments. ${ }^{9}$ Our results suggest that ASC 820 improved the information environment even more for these funds.

\footnotetext{
${ }^{8}$ Preqin's Private Equity Cash Flow Download provides fund-level information at the limited partner level, but not about the portfolio companies invested in by the private equity fund.

${ }^{9}$ See, for example, https://venturebeat.com/2009/01/15/why-fas-157-is-stupid/,

https://www.sigalow.com/2011/01/26/tis-the-season-for-valuations/
} 
We acknowledge the difficulty in testing for the effects of a change in accounting standards that happened almost concurrently with the 2008 financial crisis. Thus, we buttress our findings with controls for concurrent market moves, a difference-in-difference analysis, and a battery of robustness checks.

Our results inform private equity investors, limited partner stakeholders, industry practitioners, and policy makers as to the effectiveness of the enhanced guidance in ASC 820 in a significant segment of the financial markets. We contribute to the growing literature on private equity as well as to the literature exploring the use of fair value measurement in financial reporting.

We contribute to the private equity literature by examining a change in the accounting for its most important performance indicator, NAV, across a wide variety of fund styles (i.e., buyout, venture, real estate, and more). While Brown et al. (2017) find that venture funds' NAVs experience decreased autocorrelation after FAS 157, our findings suggest that the decreased autocorrelation results in venture funds reporting more accurate and less biased NAVs so that fund-level NAVs more closely reflect future cash flows. Whereas Crain and Law (2017) provide evidence that fair value accounting increased the valuations of the private companies in which buyout funds invest, our evidence reflects changes in private equity NAV accuracy at the fundlevel, which is the level most pertinent to private equity investors (i.e., limited partners). We also study a more complete set of private equity funds that includes venture funds, for which ASC 820 may have been more difficult to implement.

We also contribute to the literature on fair valuation as we provide evidence on the usefulness of accounting information (i.e., the NAV) as an estimate of future net distributions under previous and new GAAP guidance. Importantly, recent literature on fair value 
measurement generally explores variation across the fair value hierarchy provided by ASC 820 (i.e., comparison of Level 1 vs. Level 2 vs. Level 3). Our analyses are within the Level 3 valuation category. Our results may shed light on the effect of fair value accounting standards on the measurement of similar Level 3 type assets held by other entities outside the private equity industry.

Our paper proceeds as follows. Section 2 provides background regarding private equity, fair value, and ASC 820 and develops our research questions. In Section 3, we describe our sample and variable definitions. Section 4 provides descriptive statistics and presents our empirical tests. We discuss robustness tests in Section 5 and conclude in Section 6.

\section{PRIVATE EQUITY, FAIR VALUE, AND ASC 820}

Private equity investment continues to grow in the U.S. and globally. Private equity represents an investment strategy characterized by purchasing the equity and, sometimes, the debt of private firms (see Kaplan and Strömberg 2009 for an overview). The structure of the industry is as follows. The general partner creates and manages one or more private equity funds while the limited partners represent the fund's investors. In the typical fund life cycle, the general partner (GP) begins fundraising for a new fund and the limited partners (LPs) invest by committing a specified amount of capital. When investing in a fund, the limited partner enters into a contractual commitment entitled the Limited Partner Agreement (LPA), which outlines the limited partner's monetary commitment, general partner compensation, and fund reporting requirements. As investment opportunities in portfolio companies arise, the general partner calls invested capital from limited partners and the fund subsequently invests in those portfolio companies. Finally, the fund returns capital and profit, less a general partner management fee 
and carried interest ${ }^{10}$, to the limited partners as the fund matures and divests of its portfolio companies. It is unusual for a private equity fund to hold onto cash following such divestitures. The LPA typically calls for return of capital and profit over a ten-year fund life but fund-life extensions are possible.

Throughout the life of the fund, the general partner submits reports to the limited partners of the fund, usually on a quarterly basis. These reports typically provide timely information on exited investments and realized returns, as well as on those investments still in the portfolio, any unrealized returns, and the valuation techniques used..$^{11}$ At the same time, private equity valuation poses challenges due to its unlisted, illiquid, and non-transparent nature. For example, in an interview with a large private equity investor, we learned that it is not uncommon for two different private equity funds invested in the same underlying asset to use different valuations for that same asset. In addition, interim valuations may facilitate future fundraising, and future funds comprise a significant portion of long-run GP compensation, both in terms of management fees and carried interest (Chung, Sensoy, Stern, and Weisbach 2012; Brown et al. 2017). Recently, The Wall Street Journal and New York Times reported that the SEC's Enforcement Division has sent informal inquires to several private equity firms to gather information regarding their valuation techniques and how they report performance. ${ }^{12}$ Given the controversy and recent

\footnotetext{
${ }^{10}$ General partner compensation often follows the industry standard of 2/20 ( 2 percent management fee on all invested capital and 20 percent "carried interest" of the total return, typically after a hurdle rate is reached). Gompers and Lerner (1999) discuss compensation in the private equity industry.

${ }^{11}$ While we can observe financial statements for the subset of public private equity general partners (e.g., KKR), they are generally unavailable for private funds which make up the vast majority of the industry. A portfolio summary from InterWest is available at http://www.interwest.com/sites/default/files/PEI-Investor-RelationsManual-LP-Reporting-Chapter.pdf; this is also included in Private Equity International's Investor Relations Manual as an example of how private equity funds should report their performance to their limited partners (Holmes and Hupp 2011). Having said that, we would argue that the published reports of a public, private equity GP, either preor post-820, would not reflect the same type of reporting as received by LPs in a specific private equity fund. ${ }^{12}$ See Lattman (2012), Morgenson (2014), and Maremont and Spector (2014), as well as SEC speeches by Bowden (2014), Wyatt (2015), and Deresney (2016).
} 
lawsuits surrounding financial reporting transparency (EY 2016), this study seeks to provide insight into the reporting of private equity performance.

Most private equity funds qualify as investment companies under the Investment Companies Act of 1940 and therefore must apply Investment Company accounting under ASC 946 (see Holmes and Hupp 2011). Investment Company accounting requires that investments in underlying portfolio companies be reported at fair value. While ASC 820 provided additional guidance for how to determine fair value, the use of fair value in the private equity industry dates back to the 1970s when pension funds began to invest in private equity. Pension fund reporting required the use of fair value accounting for investments; thus, pension funds often included a GAAP (and thus, fair value) reporting requirement in the LPA. The AICPA Audit and Accounting Guide for Investment Companies, as well as various standards implemented by industry trade groups, provided guidance on the use of fair value in reporting of investments. In 2003, the Private Equity Industry Guidelines Group (PEIGG) issued U.S. Private Equity Valuation Guidelines which helped shape industry practice. These guidelines focused on estimating fair value using an entry price. In practice, private equity funds usually valued portfolio company investments at cost or at the price of the latest round of financing, which provided a new estimate of the value of the investment. This previous practice differs from ASC 820, which requires fair values to be based on an exit price. ${ }^{13}$ Implemented in 2008, ASC 820 clarified the definition and measurement of fair values in an attempt to obtain consistent estimation of fair values. Importantly, the new standard focuses on a market-based approach which may prove problematic in valuing private equity investments, which are generally highly

\footnotetext{
${ }^{13}$ In addition, the PEIGG guidelines called for interim asset-write-ups, even in the absence of a subsequent financing round. While the PEIGG guidelines, issued in 2003, were the industry standard, adoption was voluntary. Only $21 \%$ of general partners surveyed had formally adopted the 2003 PEIGG guidelines by 2005 (Blaydon and Wainwright 2005).
} 
illiquid with non-transparent market prices (which leads to Level 3 estimates under the ASC 820 fair value hierarchy).

Fair value allows general partners to monitor their investments, make asset allocation decisions, and provide timely information to their limited partners. ${ }^{14}$ Limited partners may, in turn, monitor and compare fund performance, make asset allocation decisions, and report quarterly performance information to their own investors (i.e., stakeholders in the pension, endowment, fund of funds, etc. $)^{15}$ Yet, there is little evidence on the effect of accounting standards, including those related to fair values, on this asset class, although several studies investigate the performance and risk of private equity funds (see, for example, Kaplan and Schoar 2005; Phalippou and Gottschalg 2009; Harris, Jenkinson, and Kaplan 2014; Jegadeesh, Kräussl, and Pollet 2015). An exception is Welch and Stubben (2018), who analyze the market co-movement of the returns on European private equity funds before and after the adoption of IAS 39; the authors conclude that fair value reporting requirements increased return comovement with the public markets. In addition, Brown et al. (2017) include a test of whether private equity return autocorrelation changed following the adoption of SFAS 157 (now ASC 820); they find a decrease for venture funds but not for buyout funds. Crain and Law (2017) evaluate the effect of fair value accounting on the valuations reported by the private companies in which buyout funds invest, while Ferreira, Kräussl, Landsman, Nykyforovych, and Pope

\footnotetext{
${ }^{14}$ In an opaque setting without mandatory disclosure and limited regulation, such as in private equity, financial reporting may become even more important. In a similar private setting, Cassar and Gerakos (2010) find that hedge funds voluntarily invest in internal controls over financial reporting to reduce agency costs. Moreover, hedge fund investors are willing to pay higher fees for internal controls in settings where managers have more discretion in reporting or manipulating performance. Even in private lending relationships between banks and small companies, financial reporting plays a role in a monitoring capacity (Minnis and Sutherland 2016).

${ }^{15}$ We understand that LPs have access to information from the fund GPs above and beyond that contained in the quarterly report. That said, LPs largely rely on and use the GP-provided NAV estimates in their own financial reports. To verify this, we checked through the financial reports of the four largest public investors in private equity - CPPIB, WSIB, CalPERS, and Teacher Retirement System of Texas - and we found that all of them use the NAV provided by the private equity fund's GP. For example, CPPIB states that the primary valuation technique used for private equity fund investments is the NAV provided by the investment manager. WSIB bases fair value of individual private equity investments on the valuations reported by GPs.
} 
(2018) provide evidence on the reliability and relevance of private equity funds' fair values estimates for their investee companies. Several studies suggest that managerial incentives may lead to the manipulation of reported NAVs (Barber and Yasuda 2017; Brown et al. 2017; Jenkinson, Sousa, and Stucke 2013) while a cross-country study by Cumming and Walsh (2009) finds more stringent accounting standards and stronger legal systems reduce overvaluation in private equity reporting.

A number of accounting studies investigate the effect of ASC 820 on the measurement and use of fair values in financial reporting. Several studies compare the value relevance of fair value measurements across different underlying asset types (e.g., Kolev 2009; Song et al. 2010; Goh, Li, Ng, and Yong 2015; Lawrence et al. 2016). Song et al. (2010) find that the value relevance of fair values increase along the fair value hierarchy, from Level 1 to Level 2 to Level 3. The authors argue that while fair values may be relevant, investors assign differential weighting to fair values based on their measurement inputs, suggesting potential differences in the perceived reliability of those fair values. Similarly, Riedl and Serafeim (2011) find greater information risk associated with Level 3 assets than with Level 1 and 2 assets. On the other hand, Lawrence et al. (2016) find that, in a sample of closed-end funds, Level 3 fair values are of similar value relevance to Level 1 and Level 2 fair values. In a mortgage servicing setting, Altamuro and Zhang (2013) find that valuations based on Level 3 inputs are more positively related to the persistence of future cash flows than are valuations based on Level 2 inputs. Collectively, these findings suggest that fair value estimates provide relevant information ${ }^{16}$; however, the results may vary across settings, measurement inputs, and assets.

\footnotetext{
${ }^{16}$ These findings contrast with earlier empirical work by Petroni and Wahlen (1995) who do not find the pricing of investment securities such as corporate bonds to be value relevant. Later, Carroll et al. (2003) conclude that the Petroni and Wahlen (1995) findings are most likely due to correlated omitted variables.
} 
At the same time, fair value estimates are susceptible to managerial opportunism. Early work by Beaver and Venkatachalam (2003) suggest that managerial discretion can affect the reliability of bank loan fair values. As Cotter and Richardson (2002) discuss, insiders have greater expertise related to valuing firm-specific assets. Laux and Leuz (2009) point out that, while managers may use discretion in estimating fair values, managers' litigation concerns could rein in managerial fair value estimates. It is uncertain whether litigation concerns apply to the opaque private equity setting, but at the same time, reputation and fundraising efforts may dominate private equity managerial behavior. However, aside from a test related to return autocorrelation in the appendix of Brown et al. (2017), we are unaware of any other study that explores the effect of ASC 820 on private equity funds.

We focus on two main research questions regarding private equity net asset valuation and the implementation of ASC 820.

First, we focus on liquidated private equity funds for which we can observe the full set of contributions to and distributions from the fund, in order to investigate the ability of private equity NAVs to predict future net distributions before and after ASC 820. On the one hand, fair value accounting could improve the relevance and reliability of private equity reporting. On the other hand, private equity investments are difficult to value making fair value accounting difficult to implement. Our first research question follows:

RQ1: Do private equity net asset valuations equally predict future net distributions to limited partners before and after the implementation of ASC 820 ? 
Our second research question considers the characteristics of funds where we expect ASC 820 to potentially have a differing effect. In particular, we examine cross-sectional variation across fund manager experience, fund size, and fund type.

We first consider fund manager experience. It is possible that ASC 820 implementation differentially affected managers based on their level of experience. Prior literature suggests that private equity managers are more likely to "game" returns when the fund manager has less experience (Barber and Yasuda 2017). Second, we look for differences depending on fund size. Larger funds might have better systems in place to estimate the value of their underlying investments so that smaller funds may benefit more from the implementation of ASC 820 .

Third, we consider fund strategy. For example, buyout funds generally invest in mature firms that, in turn, may have been easier to value, even before ASC 820, because they have an established pattern of cash flow generation and are more likely to have publicly-traded comparables. As another fund strategy, venture funds invest in early stage companies - often without cash generation - many of which fail and operate in less transparent reporting environments. (See Metrick and Yasuda 2010). These difficult-to-value portfolio companies often undergo numerous rounds of financing and receive investments from a number of private equity firms. As a result, interim valuation often relies on a new financing round whereas, in quarters without subsequent financing, the venture fund may carry the investment at cost until a subsequent round is undertaken. In this scenario, ASC 820 may have a potentially stronger effect through enhancing the guidance around interim valuation. On the other hand, many contended that venture investments are inherently too difficult to reliably fair value and argued ASC 820 would have little or no effect on these funds. ${ }^{17}$

Our second research question follows:

\footnotetext{
${ }^{17}$ See Mendelson (2009) and Sigalow (2011).
} 
RQ2: Did ASC 820 implementation differentially affect private equity net asset valuations based on fund and fund manager characteristics?

\section{SAMPLE DESCRIPTION AND VARIABLE DEFINITIONS}

\subsection{Sample Description}

To test for differences in reported net asset valuations before, during, and after the implementation of ASC 820 in 2008, we focus on the years 2002 through 2014. In most of our tests, we exclude the years 2007 and 2008 from our analysis as they overlap not only with the implementation of ASC 820 but also with the global financial crisis, which likely affected private equity valuations. ${ }^{18}$

The Preqin Private Equity Cash Flow Download is the primary data source for our sample and has been used in other academic studies including Ewen, Jones, and Rhodes-Kropf (2013) and Ang, Chen, Goetzmann, and Phalippou (2018). Private equity fund NAVs, contributions, and distributions (all net of fees) as well as fund size, fund manager, and fund type are obtained by Preqin from public investors in private equity via the Freedom of Information Act. ${ }^{19}$ Data in the cash flow download are scaled by Preqin to be representative of a $\$ 10$ million commitment to the fund. As of September 2017, when we obtained the Preqin download, 116,995 fund quarters from 3,492 private equity funds from 1985 to June of 2017 were available on Preqin. For each fund, we obtain from Preqin the amount of capital committed, the fund strategy, the general partners or firm with which the fund is affiliated, fund size, cash calls and distributions by date, and NAVs by quarter. We require a U.S. fund focus, because funds with Europe or Rest of World focus may be less likely to follow U.S. GAAP. Our main tests explore

\footnotetext{
${ }^{18}$ ASC 820 allowed early adoption in 2007 and required adoption in 2008.

${ }^{19}$ Harris, Jenkinson, and Kaplan (2014) obtain similar performance results using the Burgiss, Cambridge Associates, and Preqin data sets; they conclude that these three private equity data sources are unbiased.
} 
the predictive power of NAVs and adjustments to NAVs; therefore, we require a non-zero NAV at the end of the current and lagged fund-quarter. Following Phalippou and Gottschalg (2009) and Brown et al. (2017), we examine NAVs for the first ten years of the private equity fund's life. ${ }^{20}$ Finally, in order to assess private equity fund NAVs as predictors of future distributions and contributions, we limit our sample to liquidated funds, as defined by Preqin. The sample of liquidated private equity fund-quarters from 2002 to 2014 represents 9,162 fund-quarters from 432 funds. ${ }^{21}$ Panel A of Table 1 outlines our sample selection procedures.

\subsection{Net Asset Valuations (NAVs)}

Given that Preqin's private equity data is relatively new to the accounting literature, we provide below a simple description of private equity funds' reported net asset valuations. At any given point in a fund's life, the fund's NAV represents the sum of its cash contributions, or calls, to date less any distributions of realized returns to date, plus accounting recognition of estimated unrealized returns made on investments within the fund, net of fees.

$$
N A V_{Q}=\sum_{q=1}^{Q} \text { Contributions }_{q}-\sum_{q=1}^{Q} \text { Distributions }_{q}+\sum_{q=1}^{Q} \text { Valuation adjustment }_{q}-\sum_{q=1}^{Q} \text { Fees }_{q}
$$

In Equation (1), $N A V_{Q}$ is the quarterly net asset value reported by the private equity fund at quarter $Q$; Contributions $q$ represents the limited partners' contributions into the fund during quarter $q$, Distributions $q$ are distributions from the fund to its limited partners during quarter $q$,

\footnotetext{
${ }^{20}$ When we extend the sample to include all fund-quarters from the first 15 years of the fund's life, our main inferences are unchanged.

${ }^{21}$ We use all fund cash inflows and outflows during the fund's life (whether that precedes 2002 or extends to 2016) in order to both observe the fund's ex post internal rate of return and calculate NPV as of a given fund-quarter. While most of our analysis uses a 2002 to 2014 sample period, we use a sample that also includes 1996, 1997, 1998, and 1999 to conduct a difference-in-difference analysis of the effect of ASC 820.
} 
Valuation adjustment $q$ is the change in NAV from quarter $q-l$ to quarter $q$, that is not explained by contributions, distributions, and fees during the quarter, and $F e e s q$ are the fees charged by the general partner. Funds usually do not hold onto cash and thus distribute any realized returns almost immediately; therefore, the valuation adjustment should largely represent unrealized returns. Under conservative accounting, Valuation adjustment $q$ will represent only those returns that have been realized through an explicit valuation change (e.g., through the sale of assets) but have not yet been distributed. Under fair value accounting, however, Valuation adjustment $q$ will represent both undistributed, realized returns as well as the recognition of some or all unrealized returns in the form of changed (fair) value of ongoing investments.

\subsection{Calculation of Net Present Value (NPV) of Future Cash Flows}

Our first research question considers the ability of private equity fund reported NAVs to predict future discounted cash distributions and contributions. We compute the NPV of future distributions to investors less future contributions from investors, discounted by an assumed discount rate $(r)$, as in the following equation:

$$
N P V_{q}=\sum_{i=1}^{T} \frac{\text { Distributions }_{q+i}-\text { Contributions }_{q+i}}{(1+r)^{q+i}}
$$

where $q$ is the current quarter, $i$ indexes future quarters, and $T$ is the date of liquidation of the fund. The relation in equation (2) is the well-known, net present value model, in which current value is equal to the sum of the present values of all future cash flows. The relation differs from more typical applications of the net present value model that require estimation of terminal values for a lengthy, sometimes infinite, stream of future cash flows. Private equity funds with 
their short lifespans (typically 14 years, with a standard deviation of 3.7 years in our dataset) allow for observation of all future net distributions through to the end of the life of the fund.

For each fund, we first use the relation in equation (2) to calculate the internal rate of return over the entire life of the fund (which we refer to as $E N D_{-} I R R$ ). That is, we solve for the rate of return that yields a NPV of zero as of time zero, which is the date of the initial investment in the fund. ${ }^{22}$ Then, for each quarter $q$ following the initial investment in the fund, we use the fund's $E N D \_I R R$ as the discount rate to determine the net present value of future distributions and contributions from that quarter $q$ until the end of the life of the fund, $T$. Thus, we obtain a fund-specific, perfect-foresight, net present value $(N P V)$ at each quarter-end in the life of the fund.

\subsection{NAV Bias and Accuracy}

The reported NAV reflects the private equity fund managers' assessment of the value of the expected future distributions and contributions and, as such, it is a forecast of these distributions and contributions. Thus, the difference between our NPV calculation and NAV is a measure of the accuracy of the forecast just as the difference between any forecast (such as an earnings forecast) and the realized amount is an indicator of forecast accuracy.

We define NAV Biasiq as fund $i$ 's quarter $q$ reported NAV less our NPV calculation for the quarter, scaled by NAV. Thus, NAV Bias is increasing in the optimism in the NAV of the fund relative to the net present value of ex post realized net distributions. NAV Accuracyiq is the

\footnotetext{
${ }^{22}$ The internal rate of return implied by these sequences of cash flows, the sign of which changes over time (i.e., in some years there are net cash inflows and in others there are net cash outflows) may not be unique. In order to check the sensitivity of our results to this issue, we calculate the internal rate of return using starting points ("seeds") in the iterative procedure implicit in the internal rate of return ranging from 1 percent to 20 percent. In 24 funds (or $4.5 \%$ of the 432 liquidated funds in our sample), we find estimates of the implied IRR that differ by more than $1 \%$, depending upon the seed. Including or excluding these observations from our analyses has no noticeable effect on our empirical results and no effect at all on our inferences.
} 
absolute value of $N A V$ Biasiq, and is multiplied by -1 so that the variable is increasing in accuracy relative to the perfect foresight NPV. These variable definitions are similar to those used in the analyst forecast setting; for example, in Fried and Givoly (1982), accuracy is the absolute value of forecasted EPS less actual EPS, scaled by the absolute value of actual EPS. ${ }^{23}$ While bias in private equity NAVs relative to ex post future distributions is assessed in Jenkinson et al. (2016), we are unaware of any study of the accuracy of private equity fund managers' reported NAVs. In addition, the accuracy of private equity fund NAVs has not been explored in the context of ASC 820.

\section{DESCRIPTIVE STATISTICS AND EMPIRICAL TESTS}

\subsection{Descriptive Statistics}

Table 1, Panel B shows the composition of the types of funds in our sample. The funds in our sample represent a broad range of styles, with 34.3 percent of funds labeled as Buyouts and 21.5 percent as Venture. The remaining style categories include Real Estate (12.0 percent of funds), Early Stage (6.9 percent of funds), and such other categories as Distressed Debt, Growth, Mezzanine, and Natural Resources.

Panel C of Table 1 presents descriptive statistics for the sample of 432 liquidated funds and 9,162 fund-quarters from 2002 to 2014 . While the mean (median) fund in our sample raises $\$ 560$ (\$306) million of committed capital, there is a wide range of funds with an un-tabulated minimum (maximum) size of $\$ 13(\$ 6,114)$ million. The mean and median total fund life is approximately 14 years. As Figure 1 shows, cash contributions are generally largest in the early years of a fund's life, while cash distributions generally tend to be more normally distributed.

\footnotetext{
${ }^{23}$ In un-tabulated results, we obtain similar inferences in our main tests (in Table 4) when we scale by the absolute value of $N P V$ rather than by the absolute value of $N A V$.
} 
The mean (median) liquidated fund in our sample returns 170 percent (139 percent) of its investors' total cash contributions over the life of the fund.

The mean (median) values of Contributions and Distributions are $0.046(0.000)$ and 0.076 (0.000), respectively. S\&P500Return, which we use to proxy for the broader market quarterly return, has a mean (median) value of $0.010(0.016)$ across all fund-quarters in our sample. Mean (median) $E N D \_I R R$ is $0.140(0.094)$ for the sample of liquidated funds and the mean (median) values of NAV Accuracy and NAV Bias are -0.843 (-0.360) and -0.201 (0.057), respectively. Given the obvious skewness in these data, our regression analyses are based on median and robust regressions and we will focus on the median regressions for most of our inferences.

\subsection{Analysis of Private Equity Fund NAV Adjustments}

Before proceeding to the examination of our main research questions, we provide, in Table 2, a descriptive analysis of the valuation adjustments before and after the implementation of ASC 820. Column 1 reports that 96.4 percent of fund-quarters include a non-zero valuation adjustment in the sample of all 9,162 fund-quarters and this percentage changes little, increasing from 96.2 percent in the pre-2007 period (i.e., prior to ASC 820) to 96.6 percent in the post-2008 period.

For the overall sample of fund-quarters that do include valuation adjustments, 51.9 percent of adjustments are positive (see column 2 of Table 2). The percentage of positive valuation adjustments increases from 50.3 percent in the pre-2007 period to 57.7 percent in the post-2008 period, following ASC 820. These changes in the likelihood of a positive valuation adjustment could be attributable to one of two sources. ASC 820 may have resulted in a change 
in reporting behavior. Alternatively, the post-period predominately presents a time of rising market prices following the global financial crisis. Therefore, these results could be attributable to NAV's incorporating concurrent market returns associated with this rise (which we control for in subsequent tests). Columns 3 and 4 (5 and 6) assess the size of positive (negative) valuation adjustments. While positive valuation adjustments tend to be smaller in the post-period (based on medians), columns 5 and 6 suggest the size of negative valuation adjustments becomes larger. Overall, these results suggest that private equity funds make more frequent but smaller upward valuation adjustments in the period following ASC 820 implementation, which suggests that private equity funds provide more timely information to their limited partners in the post- 820 period.

\subsection{Univariate Analysis of Private Equity Fund NAV Bias and Accuracy}

Recall that our focus on liquidated private equity funds allows us to observe all distributions to and contributions from LP investors through to the end of the fund's life and to assess reported NAVs as predictors of future distributions and contributions. Table 3 presents mean and median NAV Bias and NAV Accuracy in the periods pre-2007 and post-2008. From 2002 to 2006 (the pre-period) to 2009 to 2014 (the post-period) following ASC 820 adoption, we observe a significant increase in overall median accuracy from the pre-period to the post-period. The change in bias from the pre-to the post-period is not significantly different from zero. Of course, accuracy and bias may be affected by factors other than the adoption of ASC 820. We control for these factors in our regression analyses, which follow. 


\subsection{Regression Analyses of NAV Accuracy and Bias}

We investigate the accuracy (unsigned error) and bias (signed error) of private equity NAVs as estimates of the NPV of net distributions through to the end of the fund's life, using the following regressions:

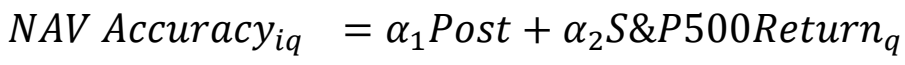

$$
\begin{aligned}
& +\alpha_{3} \text { S\&P500Return } q * \text { Post }+\alpha_{4} \text { S\&P500Return } \text { R-1 } \\
& +\alpha_{5} \text { S\&P500Return } \text { R-1 } * \text { Post }+\alpha_{6} Q 4+\alpha_{7} Q 4 * \text { Post } \\
& +\sum \text { Fund age }+\epsilon_{i q}
\end{aligned}
$$

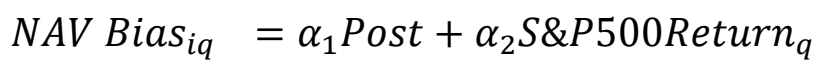

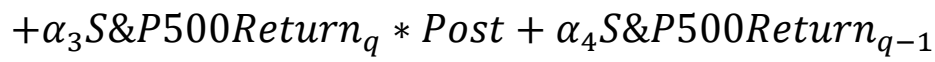

$$
\begin{aligned}
& +\alpha_{5} \text { S\&P500Return }{ }_{q-1} * \text { Post }+\alpha_{6} Q 4+\alpha_{7} Q 4 * \text { Post } \\
& +\sum \text { Fund age }+\epsilon_{i q}
\end{aligned}
$$

We include all observations for years 2002 to 2006 and 2009 to 2014 . The variable Post is an indicator variable equal to one for the years 2009 to 2014 , which are the years after the implementation of ASC 820, zero otherwise. Like Kaplan and Schoar (2005) we include the lagged and contemporaneous quarterly returns on the S\&P 500 index to control for the effects of market conditions on accuracy and bias. Like Jenkinson et al. (2013), we include a fourth-quarter indicator variable, $Q 4$, that equals one if the quarter is the fourth quarter of the fiscal year, zero otherwise. This variable is included to capture the possible effect of the annual audit in the fourth quarter on the accuracy and bias of reported NAV. We include fixed effects for fund age, which 
is the number of years since the initiation of the fund to control for changes in accuracy and bias with fund age. In a robustness check, we use number of years to liquidation instead of fund age.

If the accuracy in private equity funds' NAVs relative to future distributions improved following the implementation of ASC 820, we would expect a positive $\alpha_{1}$ coefficient in Equation (3a). Similarly, if the bias in private equity funds' NAVs relative to future distributions changed following the implementation of ASC 820, we would expect a significant $\alpha_{1}$ coefficient in Equation (3b).

Table 4 presents the results of estimating Equation (3a) in Panel A and Equation (3b) in Panel B. Given the skewness in the dependent variables, we conduct median and robust regressions, following Gipper, Leuz, and Maffett (2016) and Leone, Minutti-Meza, and Wasley (2017). Standard errors are clustered by fund for all regressions.

We find evidence of an improvement in accuracy in the years 2009 to 2014 relative to the years 2002 to 2006. In Panel A, in both the median and robust regressions, the estimate of the coefficient on Post is positive and significant ( 0.133 with a t-statistic of 4.26 and 0.084 with a tstatistic of 7.14), suggesting that NAV accuracy increased following ASC 820 implementation. Accuracy is significantly higher in the fourth quarter consistent with the annual audit in the quarter (the estimate of the coefficient on $Q 4$ is 0.049 with a t-statistic of 2.49). Interestingly, this higher fourth-quarter accuracy is not observed after the implementation of ASC 820. (The estimate of the coefficient on $Q 4 *$ Post is -0.039 - i.e., the change in the accuracy in Q4 following ASC 820 implementation is $0.049-0.039=0.010$, which is not significantly different from zero).

The results from the estimation of regression (3b) are reported in Panel B of Table 4. Although the estimate of the coefficient on Post is not significantly different from zero, the 
estimate of the coefficient on $Q 4$ is significant ( 0.050 with a t-statistic of 2.87 ) suggesting higher bias in that quarter prior to the implementation of ASC 820, consistent with private equity funds writing up valuations during the annual audit. But, this bias is not observed after the implementation of ASC 820; the estimate of the coefficient on $Q 4 *$ Post is -0.040 with a tstatistic of -2.05 (i.e., the bias in the fourth quarter after the implementation is $0.050-0.040=$ 0.010, which is not significantly different from zero). These results appear consistent with the Table 2 finding that funds make smaller, more frequent positive valuation adjustments post-ASC 820 and thus have a decreased need for upward adjustments at the year-end audit.

\subsection{Cross-sectional Analyses of NAV Accuracy and Bias}

We next proceed to analysis of cross-sectional differences in the effect of ASC 820 implementation on private equity fund NAVs. To do so, we add each of Small Fund, More Experience, and Venture (both alone and interacted with Post) to Equations (3a) and (3b), as in the following regressions:

$$
\begin{aligned}
& \text { NAV Accuracy }_{i q}=\alpha_{1} \text { Post }+\alpha_{2} \text { Small Fund }_{i}+\alpha_{3} \text { Small Fund }_{i q} * \text { Post } \\
&+\alpha_{4} \text { More Experience }_{i q}+\alpha_{5} \text { More Experience }_{i q} * \text { Post } \\
&+\alpha_{6} \text { Venture }_{i}+\alpha_{8} \text { Venture }_{i} * \text { Post }+\alpha_{9} \text { S\&P500Return }_{q} \\
&+\alpha_{10} \text { S\&P500Return }_{q} * \text { Post }+\alpha_{11} \text { S\&P500Return }_{q-1} \\
&+\alpha_{12} \text { S\&P500Return } \\
& q-1
\end{aligned}
$$




$$
\begin{aligned}
& \text { NAV Bias }_{i q}=\alpha_{1} \text { Post }+\alpha_{2} \text { Small Fund }_{i}+\alpha_{3} \text { Small Fund }_{i q} * \text { Post } \\
& +\alpha_{4} \text { More Experience }_{i q}+\alpha_{5} \text { More Experience } \text { Exq }_{i \text { Post }}
\end{aligned}
$$

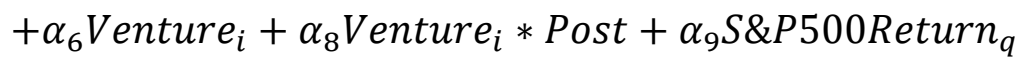

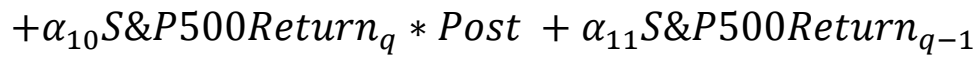

$$
\begin{aligned}
& +\alpha_{12} \text { S\&P500Return }{ }_{q-1} * \text { Post }+\alpha_{13} Q 4 \text { Indicator } \\
& +\alpha_{14} Q 4 \text { Indicator } * \text { Post }+\sum \text { Fund age }+\epsilon_{i q}
\end{aligned}
$$

The variable Small Fund is an indicator variable that equals 1 for funds with belowmedian fund size, zero otherwise. The variable More Experience is an indicator variable that equals 1 for a fund manager with more than one private equity fund, zero otherwise. The variable Venture equals 1 for venture funds, zero otherwise (and thus includes funds that invest following strategies such as buyout, real estate, and distressed debt). We report the results of estimation of Equation (4a) in Panel A of Table 5 and Equation (4b) in Panel B of Table 5. We report the results of estimation of median regressions in Column 1, and robust regressions in Column 2.

The significantly positive estimate of the coefficient on Post, which we observed when fund types were not separated in the regression, is now observed only for the estimation based on the robust regression (coefficient estimate of 0.038 with a t-statistic of 2.14 ). Recall that the estimate of this coefficient in Table 4, when all fund types were not separated, was 0.084 with a t-statistic of 7.14. The evidence in Table 5 suggests that this increase in private equity NAV accuracy is primarily driven by venture funds (the estimate of the coefficient on Venture * Post is 0.104 with a t-statistic of 3.39 ).

The striking result from the analysis of NAV bias (see Panel B), is that the bias for venture funds was significantly optimistic prior to the implementation of ASC 820 (coefficient 
estimate of 0.581 with a t-statistic of 7.55 ) and this bias significantly decreased (by 0.376 with a t-statistic of -2.59) after the implementation.

\subsection{Difference-in-difference Analyses of NAV Accuracy and Bias}

Our main analyses show that there was an increase in accuracy of NAVs following ASC 820 , a decrease in bias for venture funds, and a decrease in the Q4 bias that was observed prior to the implementation of ASC 820. In these analyses, we compared a pre-820 period, 2002 to 2006, with a post-820 period, 2009 to 2014, excluding the two years, 2007 and 2008, which were the years of the adoption of ASC 820 and the global financial crisis. In addition to excluding the years of the crisis, we also include controls to attempt to address the possible effects of changes in market conditions. However, there is a possibility that the crisis itself had lingering effects beyond 2008. To address this concern, we recognize the fact that 2000 and 2001 were years when there were major disruptions to the market in the form of the collapse of the internet bubble. This similar disruption provides a "control" set of observations for which we examine changes in accuracy pre- (i.e., 1996 through 1999) and post- (i.e., 2002 through mid-2004) the internet bubble effect. This "control" sample is compared in a difference-in-difference analysis with an ASC 820 "treatment" sample pre- (mid-2004 to 2006) and post- (2009 to 2014) ASC 820 and the global financial crisis via the following regressions: ${ }^{24}$

\footnotetext{
${ }^{24} \mathrm{We}$ include the years 2009 to 2014 in the post / treatment group in attempt to balance the number of observations in this group with other groups. In un-tabulated analysis, we limit the post / treatment group to the years 2009 and 2010 and obtain similar inferences, albeit with weaker statistical significance - possibly due to a loss of power.
} 


$$
\begin{aligned}
& \text { NAV Accuracy } \text { iq }=\alpha_{1} \text { Treatment }+\alpha_{2} \text { Post }+\alpha_{3} \text { Treatment } * \text { Post } \\
& +\alpha_{4} S \& P 500 \text { Return }_{q}+\alpha_{5} \text { S\&P500Return } q * \text { Post }
\end{aligned}
$$

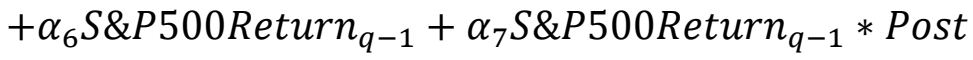

$$
\begin{aligned}
& +\alpha_{8} Q 4+\alpha_{9} Q 4 * \text { Post }+\alpha_{9} Q 4 * \text { Treatment } \\
& +\alpha_{9} Q 4 * \text { Post } * \text { Treatment }+\sum \text { Fund age }+\epsilon_{i q} \\
& \text { NAV Bias }_{i q}=\alpha_{1} \text { Treatment }+\alpha_{2} \text { Post }+\alpha_{3} \text { Treatment } * \text { Post } \\
& +\alpha_{4} S \& P 500 \text { Return }_{q}+\alpha_{5} \text { S\&P500Return } \text { R } * \text { Post } \\
& +\alpha_{6} S \& P 500 \text { Return }_{q-1}+\alpha_{7} S \& P 500 \text { Return }_{q-1} * \text { Post } \\
& +\alpha_{8} Q 4+\alpha_{9} Q 4 * \text { Post }+\alpha_{9} Q 4 * \text { Treatment } \\
& +\alpha_{9} Q 4 * \text { Post } * \text { Treatment }+\sum \text { Fund age }+\epsilon_{i q}
\end{aligned}
$$

In Equations (5a) and (5b), Treatment is set to zero for the years 1996, 1997, 1998, 1999, 2002, and 2003, as well as Q1 and Q2 of 2004, and to 1 for the periods of Q3 and Q4 of 2004 plus 2005, 2006, 2009, 2010, 2011, 2012, 2013, and 2014. (In other words, we split the 2002 through 2006 period into two.) Post is set to 1 for the periods 2002, 2003, Q1 and Q2 of 2004, 2009, $2010,2011,2012,2013$, and 2014, zero otherwise. We are interested in the estimate of the coefficient on Treatment * Post, which captures the effect of implementation of ASC 820 after controlling for the effects of a major market disruption.

Table 6 presents the results of estimating Equations (5a) and (5b). Results are consistent with our earlier analysis of NAV accuracy, with evidence of an increase in NAV accuracy following ASC 820. In particular, in Panel A of Table 6, the estimate of the coefficient on 
Treatment * Post is positive and significant in both specifications (coefficient estimates of 0.228 and 0.160 with t-statistics of 4.75 and 8.07). Also, the observed fourth quarter higher accuracy in the pre-820 period is seen again (the estimate of the coefficient on $Q 4 *$ Treatment is 0.069 with a t-statistic of 2.53) and this higher difference in fourth-quarter accuracy is significantly reduced post-820 implementation (the estimate of the coefficient on $Q 4 *$ Treatment $*$ Post is -0.108 with a t-statistic of -2.86).

The results from the estimation of regression (5b), reported in Panel B of Table 6, lead to conclusions that are quite similar to those from the estimation of regression (3b). Again the estimate of the coefficient on Treatment * Post is not significantly different from zero. The Q4 increase of 0.050 in bias prior to the implementation of ASC 820 and the decrease of 0.040 after the implementation is also observed in the Table 6, Panel B difference-in difference analysis. To see this note that the estimate of the coefficient on $Q 4$ (which is for the "control" sample) is 0.100 and the estimate of the coefficient on $Q 4 *$ Treatment is -0.051 implying that the estimate of the coefficient on $Q 4$ for the "treatment" (i.e., ASC 820) sample is $0.100-0.051=0.049$, which is remarkably similar to 0.050 . Similar the estimate of the $Q 4$ coefficient on the "treatment" sample post 820 implementation is $-0.091+0.058=-0.041$, which is remarkably similar to -0.040 .

\section{ROBUSTNESS CHECKS}

A challenge in testing for the effects of ASC 820 is that the change in accounting standard happened almost concurrently with the financial crisis. In this section we describe the un-tabulated controls and sensitivity tests we have implemented to help understand the robustness of our findings. 
Our main results exclude the years 2007 and 2008, when the credit crisis took effect. When we exclude the years 2007 and 2008, as well as 2009, from our sample, we obtain similar results in Tables 4, 5, and 6. When we include observations from 2007 in the pre- period and from 2008 in the post-period, we find that our main results in Tables 4, 5, and 6 are similar and in some cases stronger.

Our net present value $(N P V)$ calculations are based on using the $E N D \_I R R$ for each fund, i.e., the fund's internal rate of return from inception to liquidation, in order to discount future net distributions to limited partners as of a given quarter. For robustness, we assess the sensitivity of our tests by using a variety of discount rates to calculate NPVs, the choice of which is guided by the observed distribution of END_IRR for our sample of liquidated funds. As shown in Table 1, Panel C, END_IRR has a mean (median) of $14.0(9.4)$ percent and a $25^{\text {th }}$ percentile $\left(75^{\text {th }}\right.$ percentile) of 0.0 (19.4) percent. We thus re-calculate NPVs for all fund-quarters using discount rates of $0.0,9.6,14.0$, and 19.4 percent, as well as the 11.0 percent rate assumed in Jenkinson et al. (2016). In these analyses, we find the following: similar results in Table 4; consistent results for the effect of ASC 820 on venture capital funds in Table 5; and, similar results for the difference-in-difference tests for all assumed discount rates except 19.4 percent in Table 6.

Our main results use the S\&P 500 index to represent broader market returns, as in Kaplan and Schoar (2005). When we also control for the Russell 2000 and Cambridge Private Equity index returns (in both the current and lagged quarter), results are similar with the following exceptions: in the robust regression for the main analysis (column (2) of Panel A in Table 4), the coefficient on Post is no longer significantly different from zero, and in the robust regression for the difference-in-difference analysis (column (2) of Panel B in Table 6), the coefficient on 
Treatment $*$ Post is positive and significantly different from zero $(\mathrm{p}<0.05)$. All inferences based on the median regressions are unchanged when we add these additional indices.

In our main tests, we attempt to control for differences in fund age by including fund-age fixed effects. We attempt several other robustness checks and obtained similar results. First, we estimate modified versions of Equations (3a) and (3b) in which we interact each firm-age fixed effect with Post. In the accuracy tests using median regression, we continue to find evidence of an increase in accuracy in the post-ASC 820 period across most years of fund age. Second, while our main tests include fund-age fixed effects, based on the fund's age since inception, we also estimated the tests in Tables 4 through 6 including a time-to-liquidation fixed effect, based on the time remaining in the fund's life (obviously an ex post analysis), as well as including both fundage and time-to-liquidation fixed effects. In these analyses, we obtained similar results.

\section{CONCLUSION}

This study evaluates the effect of ASC 820 on valuations reported by U.S. private equity funds and, in particular, the effect of how fair value is implemented by private equity funds before and after ASC 820. This setting involves highly illiquid underlying investments that are inherently difficult to value, as well as perfect-foresight observation of all cash flows over a fund's lifetime, which negates the need for terminal value estimates. Given that private equity funds' reported NAVs are typically incorporated into the financial statements of the fund's investors, this change to the most important accounting standard for the private equity industry potentially affects a large cross-section of the capital markets.

We show that, following ASC 820 adoption, private equity fund NAVs predict ex post future net distributions to fund investors more accurately following ASC 820 implementation 
and venture funds experience a decrease in bias. Moreover, the improvement in NAV accuracy following ASC 820 appears to stem from more frequent upward adjustments to private equity fund NAVs following ASC 820 adoption. Our results suggest that enhanced fair value reporting requirements may have improved the information environment for private equity investors and their stakeholders.

Our study thus departs from fair value literature that requires market prices to evaluate the underlying relevance and/or reliability of fair value estimates (as discussed by Sloan 1999), and allows us to shed light on the financial reporting of an opaque segment of the financial markets. While we address some of the benefits of additional fair value guidance under ASC 820 , we do not attempt to address the potential increase in costs due to the new valuation guidelines. 


\section{References}

Altamuro, J., and H. Zhang. 2013. The financial reporting of fair value based on managerial inputs versus market inputs: evidence from mortgage servicing rights. Review of Accounting Studies 18 (3): 833-858.

Ang, A., B. Chen, W. Goetzmann, and L. Phalippou. 2018. Estimating private equity returns from limited partner cash flows. Journal of Finance (forthcoming).

Barber, B.M. and Yasuda, A., 2017. Interim fund performance and fundraising in private equity. Journal of Financial Economics, 124(1), pp.172-194. .

Beaver, W., and M. Venkatachalam. 2003. Differential pricing of components of bank loan fair values. Journal of Accounting, Auditing \& Finance 18: 41-67.

Blaydon, C., \& Wainwright, F. 2005. Surprise! Valuation guidelines are being adopted. Venture Capital Journal June, 1, 2005.

Bowden, A. 2014. Spreading sunshine in private equity. Speech at Private Equity International (PEI), conference, May 6, New York, NY.

Brown, G., O. Gredil, and S. Kaplan. 2017. Do private equity funds manipulate reported returns? Journal of Financial Economics (forthcoming).

Capital Dynamics. 2014. White Paper - Private Equity Secondaries. Second Edition. June 2014. https://www.capdyn.com/media/1627/white-paper-private-equity-secondaries-secondedition-jun14-en-1.pdf

Carroll, T., T. Linsmeier, and K. Petroni. 2003. The reliability of fair value versus historical cost information: Evidence from closed-end mutual funds. Journal of Accounting, Auditing \& Finance 18 (1): 1-23.

Cassar, G., and J. Gerakos. 2010. Determinants of hedge fund internal controls and fees. The Accounting Review 85 (6): 1887-1919.

Chung, J., B. Sensoy, L. Stern, and M. Weisbach. 2012. Pay for performance from future fund flows: The case of private equity. Review of Financial Studies 25 (11): 3259-3304.

Cotter, J., and S. Richardson. 2002. Reliability of asset revaluations: The impact of appraiser independence. Review of Accounting Studies 7 (4): 435-457.

Crain, N., and K. Law. 2017. The bright side of fair value accounting: Evidence from private company valuation. Vanderbilt University and Nanyang Technological University working paper.

Cumming, D., and U. Walz. 2009. Private equity returns and disclosure around the world. Journal of International Business Studies 41: 727-754. 
Deresney, A. 2016. Keynote address Private equity enforcement. Speech at Securities Enforcement Forum West conference, May 12, San Francisco, CA.

Ewen, M., C. Jones, and M. Rhodes-Kropf. 2013. The price of diversifiable risk in venture capital and private equity. Review of Financial Studies 26 (8): 1854-1889.

EY. 2016. Bridging the gap. A view into the evolving relationship between institutional investors and private equity firms.

Ferreira, P., R. Kräussl, W. Landsman, M. Nykyforovych, and P. Pope. 2018. Reliability and relevance of fair values: Private equity investments and investee fundamentals. University of North Carolina at Chapel Hill; Luxembourg School of Finance; George Mason University; and London School of Economics and Political Science working paper.

Fried, D., and D. Givoly. 1982. Financial analysts' forecasts of earnings. A better surrogate for market expectations. Journal of Accounting and Economics 1982: 85-107.

Gipper, B., C. Leuz, and M. Maffett. 2016. Public audit oversight and reporting credibility: Evidence from the PCAOB inspection regime. University of Chicago working paper.

Goh, B., D. Li, J. Ng, and K. Yong. 2009. Market pricing of banks' fair value assets reported under SFAS 157 since the 2008 economic crisis. Journal of Accounting and Public Policy 34: 129-145.

Gompers, P., and J. Lerner. 1999. An analysis of compensation in the U.S. venture capital partnership. Journal of Financial Economics 51 (1): 3-44.

Harris, R., T. Jenkinson, and S. Kaplan. 2014. Private equity performance: What do we know? The Journal of Finance 69 (5): 1851-1882.

Holmes, S. and Hupp, W. 2011. Chapter eight: Limited partner financial reporting. The Investor Relations Manual. Private Equity International. Edited by Kevin Albert.

Jegadeesh, N., R. Kräussl, and J. Pollet. 2015. Risk and expected returns of private equity investments: Evidence based on market prices. Review of Financial Studies 28 (12): 3269-3302.

Jenkinson, T., W. Landsman, B. Rountree, and K. Soonawalla. 2016. Private equity net asset values and future cash flows. University of Oxford, University of North Carolina, and Rice University working paper.

Jenkinson, T., M. Sousa, and R. Stucke. 2013. How fair are the valuations of private equity funds? University of Oxford and University of Porto working paper.

Kaplan, S.N., and A. Schoar. 2005. Private equity performance: Returns, persistence, and capital flows. The Journal of Finance 60 (4): 1791-1823. 
Kaplan, S.N., and P. Strömberg. 2009. Levered buyouts and private equity. Journal of Economic Perspectives 23 (1): 121-146.

Kolev, K. 2009. Do investors perceive marking-to-model as marking-to-myth? Early evidence from FAS 157 disclosure. Yale University working paper.

Kreutzer, L. 2009. The accounting rule formerly known as FAS 157. The Wall Street Journal. September 4, 2009.

Laux, C., and C. Leuz. 2009. The crisis of fair-value accounting: Making sense of the recent debate. Accounting, Organizations and Society 34 (6-7): 826-834.

Lattman, P., 2012. Private equity industry attracts SEC scrutiny. New York Times, February 13 2012.

Lawrence, A., J. Siriviriyakul, and R. Sloan. 2016. Who's the fairest of them all? Evidence from closed-end funds. The Accounting Review 91 (1): 207-227.

Leone, A., M. Minutti-Meza, and C. Wasley. 2017. Influential observations and inference in accounting research. University of Miami and University of Rochester working paper.

Maremont, M., and M. Spector. 2014. Buyout Firms Push to Keep Information Under Wraps. The Wall Street Journal. November 4, 2014.

Mendelson, J., 2009. 157 is Stupid. VentureBeat.com. January 15, 2009. https://venturebeat.com/2009/01/15/why-fas-157-is-stupid/

Metrick, A., and A. Yasuda. 2010. The economics of private equity funds. Review of Financial Studies 23 (6): 2303-2341.

Minnis, M., and A. Sutherland. 2016. Financial statements as monitoring mechanisms: Evidence from small commercial loans. Journal of Accounting Research 55 (1): 197-233.

Morgenson, G., 2014. Behind private equity’s curtain. New York Times. October 18, 2014.

Private Equity Industry Guidelines Group. 2003. U.S. private equity valuation guidelines. August 2003.

Petroni, K., and J. Wahlen. 1995.Fair values of equity and debt securities and share prices of property-liability insurers. The Journal of Risk and Insurance 62 (4): 719-737.

Phalippou, L., and O. Gottschalg. 2009. Performance of private equity funds. Review of Financial Studies 22 (4): 1747-1776.

Private Equity International. 2015. LP 50: The world's biggest private equity investors. "https://www.privateequityinternational.com/magazine/global/2015-07-01/privateequity $\%$ E2\% $\% 0 \% 99$ s-preferred-partners/ 
Riedl, E. J., and Serafeim, G. 2011. Information risk and fair values: An examination of equity betas. Journal of Accounting Research, 49(4), 1083-1122.Sloan, R. 1999. Evaluating the reliability of current value estimates. Journal of Accounting and Economics 26: 193-200.

Rossa, J. 2009. Putting a price tag on FAS 157. The Wall Street Journal. March 27, 2009.

Sigalow, I., 2011. 'Tis the season for valuations. Pattern Recognition, by Ian Sigalow. January 26, 2011. https://www.sigalow.com/2011/01/26/tis-the-season-for-valuations/

Song, C. J., Thomas, W. B., and Yi, H. 2010. Value relevance of FAS No. 157 fair value hierarchy information and the impact of corporate governance mechanisms. The Accounting Review, 85(4), 1375-1410.

Welch, K. T. and Stubben, S. 2018. Private equity's diversification illusion: Evidence from fair value accounting. Available at SSRN: https://ssrn.com/abstract=2379170 or http://dx.doi.org/10.2139/ssrn.2379170 .

Wyatt, M. 2015. Private equity: A look back and a glimpse ahead. Speech at Private Equity International (PEI) conference, May 13, New York, NY. 


\section{APPENDIX \\ Variable Definitions}

\begin{tabular}{|c|c|}
\hline Variable & Definition \\
\hline Contributionsiq & $\begin{array}{l}=\text { The dollar value of calls received by fund } i \text { during quarter } q \text {, } \\
\text { according to Preqin }\end{array}$ \\
\hline Distributionsiq & $\begin{array}{l}=\text { The dollar value of distributions paid by fund } i \text { during quarter } q \text {, } \\
\text { according to Preqin, multiplied by }-1\end{array}$ \\
\hline$E N D_{-} I R R_{i}$ & $\begin{array}{l}=\text { The internal rate of return realized by a liquidated fund over its } \\
\text { entire life }\end{array}$ \\
\hline $\mathrm{Fees}_{q}$ & $=$ The fees charged to the private equity fund by the general partner \\
\hline Fund Sizeiq & $\begin{array}{l}=\text { The total commitments to a private equity fund, measured in } \\
\text { millions of dollars, according to Preqin, where commitments are } \\
\text { the specified sum of capital a limited partner has agreed to } \\
\text { contribute to a private equity fund }\end{array}$ \\
\hline More Experience & $\begin{array}{l}=\text { Indicator variable that equals } 1 \text { for a fund manager with more } \\
\text { than one private equity fund and equals } 0 \text { otherwise }\end{array}$ \\
\hline$N A V_{i q}$ & $\begin{aligned}= & \text { Net asset value reported by fund } i \text { at the end of the quarter } q \text {, } \\
& \text { according to Preqin }\end{aligned}$ \\
\hline NAV Accuracyiq & $\begin{array}{l}=\text { The absolute value of } N A V \text { Biasiq, multiplied by }-1 \text { so that this } \\
\text { variable is increasing in accuracy }\end{array}$ \\
\hline NAV Biasiq & $=N A V_{i q}-N P V_{i q}$, scaled by $N A V_{i q}$ \\
\hline$N P V_{i q}$ & $\begin{array}{l}=\text { Future quarterly net distributions (distributions less contributions) } \\
\text { to limited partners from quarter } q+1 \text { to fund liquidation, } \\
\text { discounted at the internal rate of return ultimately realized by the } \\
\text { fund }\left(E N D_{-} I R R_{\mathrm{i}}\right)\end{array}$ \\
\hline Post & $\begin{array}{l}=\text { Indicator variable that equals } 1 \text { for the years following } 2008 \text { and } \\
\text { zero for the years preceding } 2007\end{array}$ \\
\hline Q4 & $\begin{array}{l}=\text { Indicator variable that equals } 1 \text { during the fourth calendar quarter } \\
\text { and equals } 0 \text { otherwise }\end{array}$ \\
\hline Small Fund & $\begin{array}{l}=\text { Indicator variable that equals } 1 \text { for a fund with below median fund } \\
\text { size, and equals } 0 \text { otherwise }\end{array}$ \\
\hline S\&P500Return $q$ & $\begin{array}{l}=\text { The CRSP quarterly return on the S\&P500 index (SPRTRN), } \\
\text { compounded monthly during quarter } q\end{array}$ \\
\hline Valuation adjustmentiq & $\begin{array}{l}=\text { The change in NAV from quarter } q-1 \text { to quarter } q \text {, that is not } \\
\text { explained by contributions and distributions during the quarter }\end{array}$ \\
\hline Venture & $\begin{array}{l}=\text { Indicator variable that equals } 1 \text { for a venture fund and equals } 0 \\
\text { otherwise }\end{array}$ \\
\hline
\end{tabular}


FIGURE 1

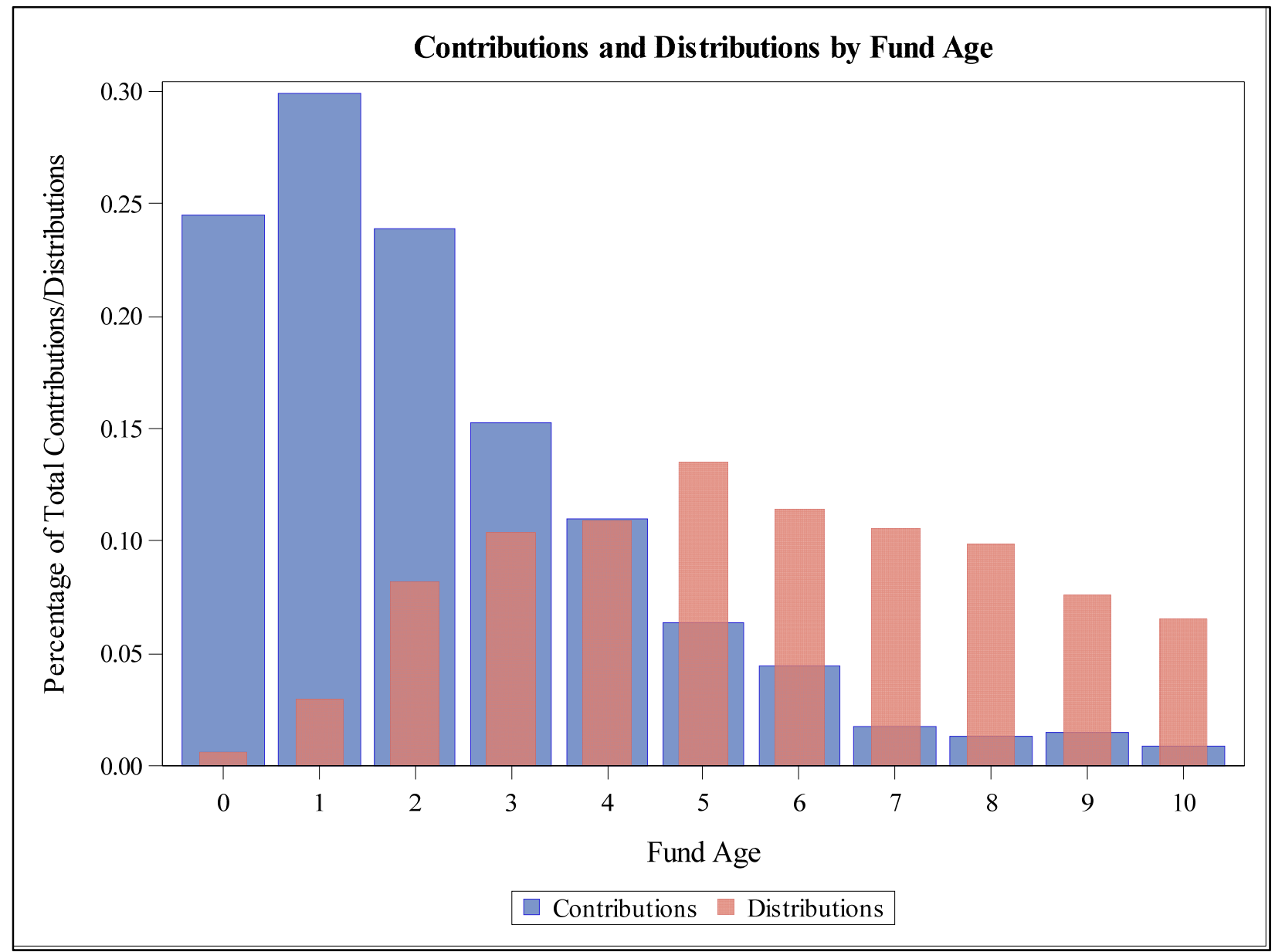

Note: This graph represents data from the full sample of liquidated funds with fund-age $<=10$ for years 2002 to 2014 . 
TABLE 1

Sample Selection and Descriptive Statistics

This table contains details regarding sample selection (in Panel A), the breakdown of funds by investment strategy (in Panel B); and descriptive statistics for the sample of funds (in Panel C). Variable definitions are in the Appendix.

\section{Panel A: Sample selection}

\begin{tabular}{|c|c|c|c|c|c|}
\hline & $\begin{array}{c}\text { Fund } \\
\text { Quarters } \\
\end{array}$ & $\begin{array}{l}\text { Unique } \\
\text { Funds }\end{array}$ & $\begin{array}{l}\text { Unique } \\
\text { Firms }\end{array}$ & $\begin{array}{l}\text { Unique } \\
\text { Years }\end{array}$ & $\begin{array}{c}\text { Unique } \\
\text { Vintage } \\
\text { Years }\end{array}$ \\
\hline Initial Preqin Sample & 116,995 & 3,492 & 1,396 & 35 & 38 \\
\hline Require US fund focus & 94,950 & 2,665 & 1,035 & 35 & 38 \\
\hline Require NAV $>0$ & 80,063 & 2,650 & 1,035 & 35 & 35 \\
\hline Require lag NAV & 74,167 & 2,565 & 1,003 & 35 & 33 \\
\hline Require non-missing fund size & 72,113 & 2,475 & 981 & 35 & 33 \\
\hline Limit sample to 2002 to 2014 & 51,519 & 2,104 & 889 & 13 & 30 \\
\hline Funds with fund-age $<=10,2002$ to 2014 & 42,826 & 2,061 & 874 & 13 & 23 \\
\hline Liquidated funds with fund-age $<=10,2002$ to 2014 & 9,162 & 432 & 275 & 13 & 22 \\
\hline
\end{tabular}

\section{Panel B: Breakdown of funds by investment strategy}

\begin{tabular}{|l|c|c|}
\hline \hline & \multicolumn{2}{c}{ Unique Funds } \\
Investment Strategy & $\#$ & $\%$ \\
\hline Balanced & 9 & 2.1 \\
Buyout & 148 & 34.3 \\
Direct Lending & 1 & 0.2 \\
Distressed Debt & 30 & 3.7 \\
Early Stage & 1 & 6.9 \\
Early Stage: Start-up & 14 & 0.2 \\
Expansion / Late Stage & 2 & 3.2 \\
Fund of Funds & 12 & 0.5 \\
Growth & 4 & 2.8 \\
Infrastructure & 26 & 0.9 \\
Mezzanine & 12 & 6.0 \\
Natural Resources & 52 & 2.8 \\
Real Estate & 7 & 12.0 \\
Secondaries & 2 & 1.6 \\
Timber & 1 & 0.5 \\
Turnaround & 93 & 0.2 \\
Venture (General) & 21.5 \\
Venture Debt & \multicolumn{2}{|c|}{} \\
\hline Total & 432 & 100 \\
\hline \hline
\end{tabular}


TABLE 1 (continued)

Panel C: Descriptive statistics for funds and fund-quarters

\begin{tabular}{|c|c|c|c|c|c|c|c|c|}
\hline & $\mathrm{N}$ & Mean & Std Dev & $\mathrm{P} 5$ & Q1 & Median & Q3 & P95 \\
\hline \multicolumn{9}{|l|}{ Funds } \\
\hline$\overline{\text { Fund Size (\$ million) }}$ & 432 & 560 & 796 & 55 & 150 & 306 & 598 & 2,000 \\
\hline Total Fund Life (in Years) & 432 & 13.8 & 3.7 & 7 & 12 & 14 & 16 & 19 \\
\hline Total Contributions & 432 & $9,866,089$ & $1,172,351$ & $8,167,150$ & $9,700,001$ & $10,000,000$ & $10,001,594$ & $11,389,880$ \\
\hline Total Distributions & 432 & $16,812,534$ & $19,469,057$ & $2,334,836$ & $8,968,825$ & $13,415,200$ & $18,847,713$ & $37,560,001$ \\
\hline Total Distributions/Total Contributions & 432 & 1.702 & 1.952 & 0.254 & 0.906 & 1.390 & 1.887 & 3.756 \\
\hline$E N D \_I R R$ & 432 & 0.140 & 0.392 & -0.195 & -0.000 & 0.094 & 0.194 & 0.570 \\
\hline \multicolumn{9}{|l|}{ Fund-quarters } \\
\hline$N A V_{i q}$ & 9,162 & $3,976,612$ & $2,833,086$ & 313,020 & $1,795,330$ & $3,487,275$ & $5,632,430$ & $9,277,540$ \\
\hline Net Present Value $\left(N P V_{i q}\right)$ & 9,162 & $3,669,011$ & $3,555,159$ & $-53,310$ & 861,984 & $2,865,460$ & $5,919,787$ & $10,208,748$ \\
\hline NAV Accuracy & 9,162 & -0.843 & 17.833 & -1.757 & -0.708 & -0.360 & -0.146 & -0.024 \\
\hline NAV Bias $i q$ & 9,162 & -0.201 & 17.852 & -1.139 & -0.252 & 0.057 & 0.477 & 1.036 \\
\hline Valuation adjustment ${ }_{i q} / N A V_{i q-1}$ & 9,162 & 0.176 & 10.788 & -0.217 & -0.034 & 0.000 & 0.048 & 0.268 \\
\hline$\Delta N A V_{i q} / N A V_{i q-1}$ & 9,162 & 0.146 & 10.790 & -0.388 & -0.094 & -0.007 & 0.042 & 0.342 \\
\hline Contributions $_{i q} / N A V_{i q-1}$ & 9,162 & 0.046 & 0.359 & 0.000 & 0.000 & 0.000 & 0.007 & 0.228 \\
\hline Distributionsiq/NAV $V_{i q-1}$ & 9,162 & -0.076 & 0.272 & -0.393 & -0.065 & 0.000 & 0.000 & 0.000 \\
\hline S\&P500Return ${ }_{q}$ & 9,162 & 0.010 & 0.082 & -0.142 & -0.026 & 0.016 & 0.058 & 0.149 \\
\hline$Q 4_{q}$ & 9,162 & 0.219 & 0.413 & 0.000 & 0.000 & 0.000 & 0.000 & 1.000 \\
\hline
\end{tabular}


TABLE 2

\section{Valuation Adjustments of Liquidated Private Equity Funds}

This table explores the valuation adjustments made by liquidated private equity funds in the fund-quarters before, after, and spanning implementation of ASC 820 (SFAS 157). Panel A presents the frequency of fund-quarters that include a non-zero valuation adjustment (Column 1), the frequency of fund-quarters with non-zero valuation adjustments that include positive valuation adjustments (Column 2), and the size of valuation adjustments (Valuation adjustment) scaled by lagged NAV (Columns 3 through 6), in the years 2002 through 2014. Panel B presents the same statistics for the periods before and after ASC 820 (2002 to 2006 and 2009 to 2014, respectively), as well as tests of the difference between these two periods. $* * *, * *$, and $*$ denote significance at the $1 \%, 5 \%$ and $10 \%$ levels, respectively, based on two-tailed tests. All variables are defined in the Appendix.

Panel A: Valuation adjustments by year

\begin{tabular}{|cc|r|r|c|c|c|c|}
\hline \hline Year & \multicolumn{1}{c|}{$\mathrm{N}$} & $\begin{array}{c}\text { Valuation } \\
\text { adjustment } \neq 0\end{array}$ & $\begin{array}{c}\text { Valuation } \\
\text { adjustment }>0\end{array}$ & \multicolumn{2}{|c|}{$\begin{array}{c}\text { Valuation adjustment } \\
(>0)\end{array}$} & \multicolumn{2}{|c|}{$\begin{array}{c}\text { Valuation adjustment } \\
(<0)\end{array}$} \\
\hline & & $(1)$ & $(2)$ & $(3)$ & $(4)$ & $(5)$ & $(6)$ \\
2002 & & & Mean & Median & Mean & Median \\
2003 & 1,000 & $966(96.6 \%)$ & $444(46.0 \%)$ & 2.382 & 0.047 & -0.066 & -0.033 \\
2004 & 1,153 & $1,106(95.9 \%)$ & $590(53.3 \%)$ & 0.132 & 0.062 & -0.073 & -0.033 \\
2005 & 1,102 & $1,049(95.2 \%)$ & $584(55.7 \%)$ & 0.155 & 0.059 & -0.066 & -0.034 \\
2006 & 1,017 & $967(95.1 \%)$ & $593(61.3 \%)$ & 0.156 & 0.059 & -0.071 & -0.024 \\
2007 & 954 & $935(98.0 \%)$ & $552(59.0 \%)$ & 0.637 & 0.050 & -0.078 & -0.031 \\
2008 & 815 & $782(96.0 \%)$ & $296(37.9 \%)$ & 0.493 & 0.036 & -0.138 & -0.066 \\
2009 & 692 & $669(96.7 \%)$ & $315(47.1 \%)$ & 0.152 & 0.046 & -0.125 & -0.049 \\
2010 & 501 & $482(96.2 \%)$ & $294(61.0 \%)$ & 0.113 & 0.053 & -0.072 & -0.032 \\
2011 & 345 & $332(96.2 \%)$ & $209(63.0 \%)$ & 0.096 & 0.047 & -0.075 & -0.031 \\
2012 & 277 & $266(96.0 \%)$ & $162(60.9 \%)$ & 0.063 & 0.036 & -0.117 & -0.050 \\
2013 & 206 & $200(97.1 \%)$ & $131(65.5 \%)$ & 0.320 & 0.033 & -0.077 & -0.039 \\
2014 & 159 & $157(98.7 \%)$ & $104(66.2 \%)$ & 0.075 & 0.038 & -0.161 & -0.035 \\
$2002-2014$ & 9,162 & $8,836(96.4 \%)$ & $4,583(51.9 \%)$ & 0.436 & 0.048 & -0.090 & -0.040 \\
& & & & & & & \\
\hline \hline
\end{tabular}

Panel B: Valuation adjustments before and after ASC 820

\begin{tabular}{|lc|c|c|c|c|c|c|}
\hline \hline & & \multicolumn{1}{c|}{$\begin{array}{c}\text { Valuation } \\
\text { Year }\end{array}$} & $\mathrm{N}$ & $\begin{array}{c}\text { Valuation } \\
\text { adjustment } \neq 0\end{array}$ & \multicolumn{2}{|c|}{$\begin{array}{c}\text { Valuation adjustment } \\
\text { adjustment }>0\end{array}$} & \multicolumn{2}{|c|}{$\begin{array}{c}\text { Valuation adjustment } \\
(<0)\end{array}$} \\
\hline $2002-2006$ & 5,213 & $5,013(96.2 \%)$ & $2,520(50.3 \%)$ & 0.532 & 0.053 & -0.078 & -0.036 \\
$2009-2014$ & 2,180 & $2,106(96.6 \%)$ & $1,215(57.7 \%)$ & 0.132 & 0.041 & -0.104 & -0.042 \\
\hline $2002-2006$ & & & $* * *$ & & & & $* * *$ \\
vs. 2009-2014 & & & & $* * *$ & $* *$ \\
\hline \hline
\end{tabular}


TABLE 3

Accuracy and Bias of Liquidated Private Equity NAV Disclosures

This table provides descriptive statistics regarding the accuracy and bias of liquidated private equity fund NAV disclosures relative to future net distributions discounted back at the internal rate of return ultimately realized by the fund from inception to liquidation $(E N D I R R)$ for the periods before and after ASC 820 (2002 to 2006 and 2009 to 2014, respectively), as well as tests of the difference between these two periods. $* * *, * *$, and $*$ denote significance at the $1 \%, 5 \%$ and $10 \%$ levels, respectively, based on two-tailed tests. All variables are defined in the Appendix.

\begin{tabular}{|lc|c|c|c|c|}
\hline \hline Years & $\mathrm{N}$ & $\begin{array}{c}\text { Mean } \\
\text { Accuracy }\end{array}$ & $\begin{array}{c}\text { Median } \\
\text { Accuracy }\end{array}$ & $\begin{array}{c}\text { Mean } \\
\text { Bias }\end{array}$ & $\begin{array}{c}\text { Median } \\
\text { Bias }\end{array}$ \\
\hline $2002-2006$ & 5,213 & -0.959 & -0.392 & -0.318 & 0.004 \\
$2009-2014$ & 2,180 & -0.693 & -0.271 & -0.195 & 0.025 \\
\hline $2002-2006$ & & $* * *$ & & \\
vs. 2009-2014 & & $* * *$ & \\
\hline
\end{tabular}


TABLE 4

\section{Accuracy and Bias of Liquidated Private Equity NAV Disclosures}

This table assesses the accuracy and bias of liquidated private equity fund NAV disclosures relative to the net present value of future net distributions discounted back at the internal rate of return ultimately realized by the fund from inception to liquidation (END_IRR). The variable Post equals zero for the firm quarters prior to 2007, and one for the firm-quarters after 2008. We estimate the following equations for the years 2002 to 2014 but excluding 2007 and 2008 :

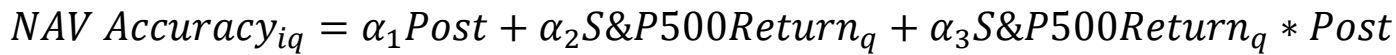
$+\alpha_{4} S \& P 500$ Return $_{q-1}+\alpha_{5}$ S\&P500Return ${ }_{q-1} *$ Post $+\alpha_{6} Q 4+\alpha_{7} Q 4 *$ Post $+\sum$ Fund age $+\epsilon_{i q}$

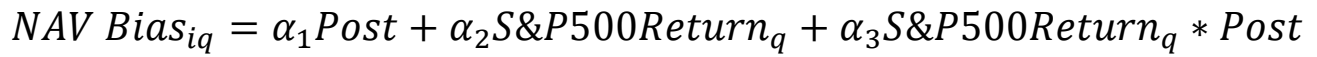
$+\alpha_{4} S \& P 500$ Return $_{q-1}+\alpha_{5}$ S\&P500Return R-1 $*$ Post $+\alpha_{6} Q 4+\alpha_{7} Q 4 *$ Post $+\sum$ Fund age $+\epsilon_{i q}$

Panels A and B respectively present results for NAV accuracy and NAV bias. Column (1) uses median regression and Column (2) uses robust regression. All 11 fund age fixed effects are included (for years 0 through 10 of fund age) and thus intercepts are suppressed. Coefficients are presented with standard errors in parentheses; standard errors are clustered by fund. ***, **, and $*$ denote significance at the $1 \%, 5 \%$ and $10 \%$ levels, respectively, based on two-tailed tests. All variables are defined in the Appendix. 
TABLE 4 (continued)

Panel A: NAV accuracy

\begin{tabular}{|c|c|c|c|c|c|c|}
\hline & & Me & & & Ro & \\
\hline & Coefficient & & T-stat. & Coefficient & & T-stat. \\
\hline Post & 0.133 & $* * *$ & 4.26 & 0.084 & $* * *$ & 7.14 \\
\hline S\&P500Return ${ }_{q}$ & -0.076 & & -0.68 & -0.065 & & -0.76 \\
\hline S\&P500Return ${ }_{q}^{*}$ Post & 0.121 & & 0.99 & 0.040 & & 0.33 \\
\hline $\mathrm{S} \& \mathrm{P} 500$ Return $_{\mathrm{q}-1}$ & -0.077 & & -0.93 & -0.103 & & -1.33 \\
\hline S\&P500Return $q$-1 $*$ Post & 0.177 & $*$ & 1.68 & 0.179 & $*$ & 1.71 \\
\hline Q4 & 0.049 & ** & 2.49 & 0.042 & $* * *$ & 2.89 \\
\hline Q4 * Post & -0.039 & & -1.62 & -0.025 & & -1.02 \\
\hline Fixed Effects? & & Fun & & & Fun & \\
\hline Observations & & & & & & \\
\hline Number of funds & & & & & & \\
\hline R-squared & & & & & & \\
\hline Pseudo R-squared & & & & & & \\
\hline
\end{tabular}

Panel B: NAV bias

\begin{tabular}{|c|c|c|c|c|c|c|}
\hline & & & & & & \\
\hline & Coefficient & & T-stat. & Coefficient & & T-stat. \\
\hline Post & 0.022 & & 0.59 & 0.003 & & 0.14 \\
\hline S\&P500Return & -0.207 & * & -1.83 & -0.487 & $* * *$ & -3.58 \\
\hline S\&P500Return $_{\mathrm{q}} *$ Post & 0.034 & & 0.26 & 0.276 & & 1.39 \\
\hline S\&P500Return & 0.055 & & 0.62 & 0.064 & & 0.52 \\
\hline S\&P500Return ${ }_{\mathrm{q}-1} *$ Post & -0.159 & & -1.26 & -0.184 & & -1.09 \\
\hline Q4 & 0.050 & $* * *$ & 2.87 & 0.066 & $* * *$ & 2.87 \\
\hline Q4 * Post & -0.040 & $* *$ & -2.05 & -0.054 & & -1.39 \\
\hline Fixed Effects? & & Fun & & & Fun & \\
\hline Observations & & & & & & \\
\hline Number of funds & & & & & & \\
\hline R-squared & & & & & & \\
\hline Pseudo R-squared & & & & & & \\
\hline
\end{tabular}




\section{TABLE 5 \\ Cross-sectional Analysis of Accuracy and Bias of Liquidated Private Equity NAV Disclosures}

This table assesses the accuracy and bias of liquidated private equity fund NAV disclosures relative to future net distributions discounted back at the internal rate of return ultimately realized by the fund from inception to liquidation $\left(E N D_{-} I R R\right)$. The variable Post equals zero for the firm quarters prior to 2007, and one for the firm-quarters after 2008. We estimate versions of the following equations for the years 2002 to 2014 but excluding 2007 and 2008:

$N A V$ Accuracy $_{i q}=\alpha_{1}$ Post $+\alpha_{2}$ Small Fund $_{i}+\alpha_{3}$ Small Fund $_{i q} *$ Post

$+\alpha_{4}$ More Experience $_{i q}+\alpha_{5}$ More Experience Eq $_{i} *$ Post

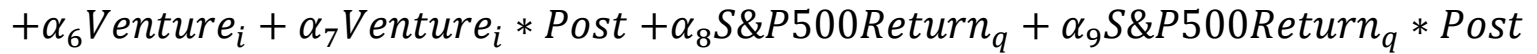

$+\alpha_{10}$ S\&P500Return ${ }_{q-1}+\alpha_{11} S \& P 500$ Return $_{q-1} *$ Post $+\alpha_{12} Q 4+\alpha_{13} Q 4 *$ Post

$+\sum$ Fund age $+\epsilon_{i q}$

NAV Bias $_{i q}=\alpha_{1}$ Post $+\alpha_{2}$ Small Fund $_{i}+\alpha_{3}$ Small Fund $_{i q} *$ Post

$+\alpha_{4}$ More Experience $_{i q}+\alpha_{5}$ More Experience Ex $_{i q}$ Post

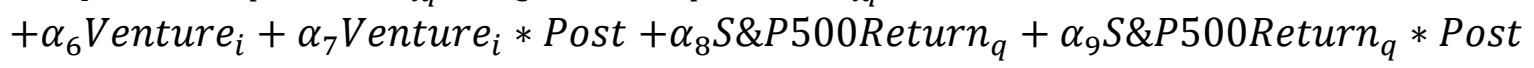

$+\alpha_{10} S \& P 500$ Return $_{q-1}+\alpha_{11} S \& P 500$ Return $_{q-1} *$ Post $+\alpha_{12} Q 4+\alpha_{13} Q 4 *$ Post

$+\sum$ Fund age $+\epsilon_{i q}$

Panels A and B respectively present results for NAV accuracy and NAV bias. Column (1) uses median regression and column (2) uses robust regression. All 11 fund age fixed effects are included (for years 0 through 10 of fund age) and thus intercepts are suppressed. Coefficients are presented with standard errors in parentheses; standard errors are clustered by fund. ***, **, and $*$ denote significance at the $1 \%, 5 \%$ and $10 \%$ levels, respectively, based on two-tailed tests. All variables are defined in the Appendix. 
TABLE 5 (continued)

Panel A: NAV accuracy

\begin{tabular}{|c|c|c|c|c|c|c|}
\hline & \multicolumn{3}{|c|}{$\begin{array}{c}\text { Median } \\
\text { (1) }\end{array}$} & \multicolumn{3}{|c|}{$\begin{array}{l}\text { Robust } \\
\text { (2) }\end{array}$} \\
\hline & Coefficient & & T-stat. & Coefficient & & T-stat. \\
\hline Post & 0.071 & & 1.61 & 0.038 & ** & 2.14 \\
\hline Small Fund & -0.156 & $* * *$ & -3.78 & -0.143 & $* * *$ & -13.40 \\
\hline Small Fund * Post & -0.031 & & -0.45 & -0.017 & & -0.87 \\
\hline More Experience & 0.020 & & 0.52 & 0.006 & & 0.61 \\
\hline More Experience $*$ Post & -0.058 & & -0.98 & -0.034 & * & -1.82 \\
\hline Venture & -0.235 & $* * *$ & -4.40 & -0.184 & $* * *$ & -14.97 \\
\hline Venture $*$ Post & 0.128 & & 1.48 & 0.104 & $* * *$ & 3.39 \\
\hline S\&P500Return $_{\mathrm{q}}$ & 0.032 & & 0.33 & -0.095 & & -1.18 \\
\hline S\&P500Return $*$ Post & 0.042 & & 0.37 & 0.090 & & 0.77 \\
\hline S\&P500Return & -0.029 & & -0.38 & -0.120 & * & -1.65 \\
\hline S\&P500Return $_{\mathrm{q}-1} *$ Post & 0.170 & & 1.60 & 0.182 & $*$ & 1.83 \\
\hline Q4 & 0.008 & & 0.55 & 0.029 & ** & 2.16 \\
\hline Q4 * Post & 0.005 & & 0.25 & -0.011 & & -0.49 \\
\hline Fixed Effects? & \multicolumn{3}{|c|}{ Fund age } & \multicolumn{3}{|c|}{ Fund age } \\
\hline Observations & \multicolumn{3}{|c|}{7,393} & \multicolumn{3}{|c|}{7,393} \\
\hline Number of funds & \multicolumn{3}{|c|}{432} & \multicolumn{3}{|c|}{432} \\
\hline R-squared & & & & \multirow{2}{*}{\multicolumn{3}{|c|}{0.217}} \\
\hline Pseudo R-squared & \multicolumn{3}{|c|}{0.032} & & & \\
\hline
\end{tabular}

\section{Panel B: NAV bias}

\begin{tabular}{|c|c|c|c|c|c|c|}
\hline & & $\mathbf{M e}$ & & & Ro & \\
\hline & Coefficient & & T-stat. & Coefficient & & T-stat. \\
\hline Post & 0.081 & & 1.54 & 0.092 & $* * *$ & 3.31 \\
\hline Small Fund & -0.008 & & -0.14 & 0.020 & & 1.23 \\
\hline Small Fund * Post & 0.025 & & 0.30 & 0.073 & $* * *$ & 2.38 \\
\hline More Experience & -0.044 & & -0.85 & -0.034 & $* *$ & -2.19 \\
\hline More Experience $*$ Post & 0.015 & & 0.22 & 0.006 & & 0.22 \\
\hline Venture & 0.581 & $* * *$ & 7.55 & 0.491 & $* * *$ & 25.67 \\
\hline Venture $*$ Post & -0.376 & $* * *$ & -2.59 & -0.397 & $* * *$ & -8.33 \\
\hline S\&P500Return $_{\mathrm{q}}$ & -0.296 & $* * *$ & -2.97 & -0.448 & $* * *$ & -3.56 \\
\hline S\&P500Return ${ }_{\mathrm{q}} *$ Post & 0.136 & & 1.08 & 0.227 & & 1.24 \\
\hline S\&P500Return ${ }_{\mathrm{q}-1}$ & 0.195 & $* *$ & 2.16 & 0.096 & & 0.84 \\
\hline S\&P500Return ${ }_{\mathrm{q}-1} *$ Post & -0.272 & $* *$ & -2.27 & -0.198 & & -1.28 \\
\hline Q4 & 0.077 & $* * *$ & 4.24 & 0.083 & $* * *$ & 3.92 \\
\hline Q4 * Post & -0.068 & $* * *$ & -3.16 & -0.072 & $* *$ & -2.02 \\
\hline Fixed Effects? & & Fun & & & Fun & \\
\hline Observations & & & & & & \\
\hline Number of funds & & & & & & \\
\hline R-squared & & & & & & \\
\hline Pseudo R-squared & & & & & & \\
\hline
\end{tabular}


TABLE 6

Diff-in-Diff Analysis of Accuracy and Bias of Liquidated Private Equity NAV Disclosures

This table assesses the accuracy and bias of liquidated private equity fund NAV disclosures relative to future net distributions discounted back at the internal rate of return ultimately realized by the fund from inception to liquidation $\left(E N D_{-} I R R\right)$. We estimate versions of the following equations:

NAV Accuracy iq $=\alpha_{1}$ Treatment $+\alpha_{2}$ Post $+\alpha_{3}$ Treatment $*$ Post $+\alpha_{4}$ Fund Size ${ }_{i}$

$+\alpha_{5}$ Fund Size $_{i} *$ Post $+\alpha_{6}$ S\&P500Return $q+\alpha_{7}$ S\&P500Return $q *$ Post

$+\alpha_{8} S \& P 500$ Return $_{q-1}+\alpha_{9} S \& P 500$ Return $_{q-1} *$ Post $+\alpha_{10} Q 4+\alpha_{11} Q 4 *$ Post

$+\alpha_{11} Q 4 *$ Treatment $+\alpha_{11} Q 4 *$ Post $*$ Treatment $+\sum$ Fund age $+\epsilon_{i q}$

NAV Bias iq $_{1}=\alpha_{1}$ Treatment $+\alpha_{2}$ Post $+\alpha_{3}$ Treatment $*$ Post $+\alpha_{4}$ Fund Size ${ }_{i}$

$+\alpha_{5}$ Fund Size $_{i} *$ Post $+\alpha_{6}$ S\&P500Return $q+\alpha_{7}$ S\&P500Return $q *$ Post

$+\alpha_{8} S \& P 500$ Return $_{q-1}+\alpha_{9} S \& P 500$ Return $_{q-1} *$ Post $+\alpha_{10} Q 4+\alpha_{11} Q 4 *$ Post

$+\alpha_{11} Q 4 *$ Treatment $+\alpha_{11} Q 4 *$ Post $*$ Treatment $+\sum$ Fund age $+\epsilon_{i q}$

The tests use a matched sample of funds from 1996, 1997, 1998, 1999, 2002, 2003, 2004, 2005, 2006, 2009, 2010, 2011, 2012, 2013, and 2014. The years 1996, 1997, 1998, 1999, 2002, and 2003 plus Q1 and Q2 of 2004 serve as the control group, and Q3 and Q4 of 2004 and the years 2005, 2006, 2009, 2010, 2011, 2012, 2013, and 2014 serve as the treatment group. Thus,

Treatment $=1$ for Q3 and Q4 of 2004 and the years 2005, 2006, 2009, 2010, 2011, 2012, 2013, and 2014 and Treatment $=0$ for the years 1996, 1997, 1998, 1999, 2002, and 2003 plus Q1 and Q2 of 2004. Post $=1$ for the years 2002 and 2003 plus Q1 and Q2 of 2004, and for the years 2009, 2010, 2011, 2012, 2013, and 2014.

Panels A and B respectively present results for NAV accuracy and NAV bias. Column (1) uses median regression and column (2) uses robust regression. All 11 fund age fixed effects are included (for years 0 through 10 of fund age) and thus intercepts are suppressed. Coefficients are presented with standard errors in parentheses; standard errors are clustered by fund. ***,**, and $*$ denote significance at the $1 \%, 5 \%$ and $10 \%$ levels, respectively, based on two-tailed tests. All variables are defined in the Appendix. 
TABLE 6 (continued)

Panel A: NAV accuracy

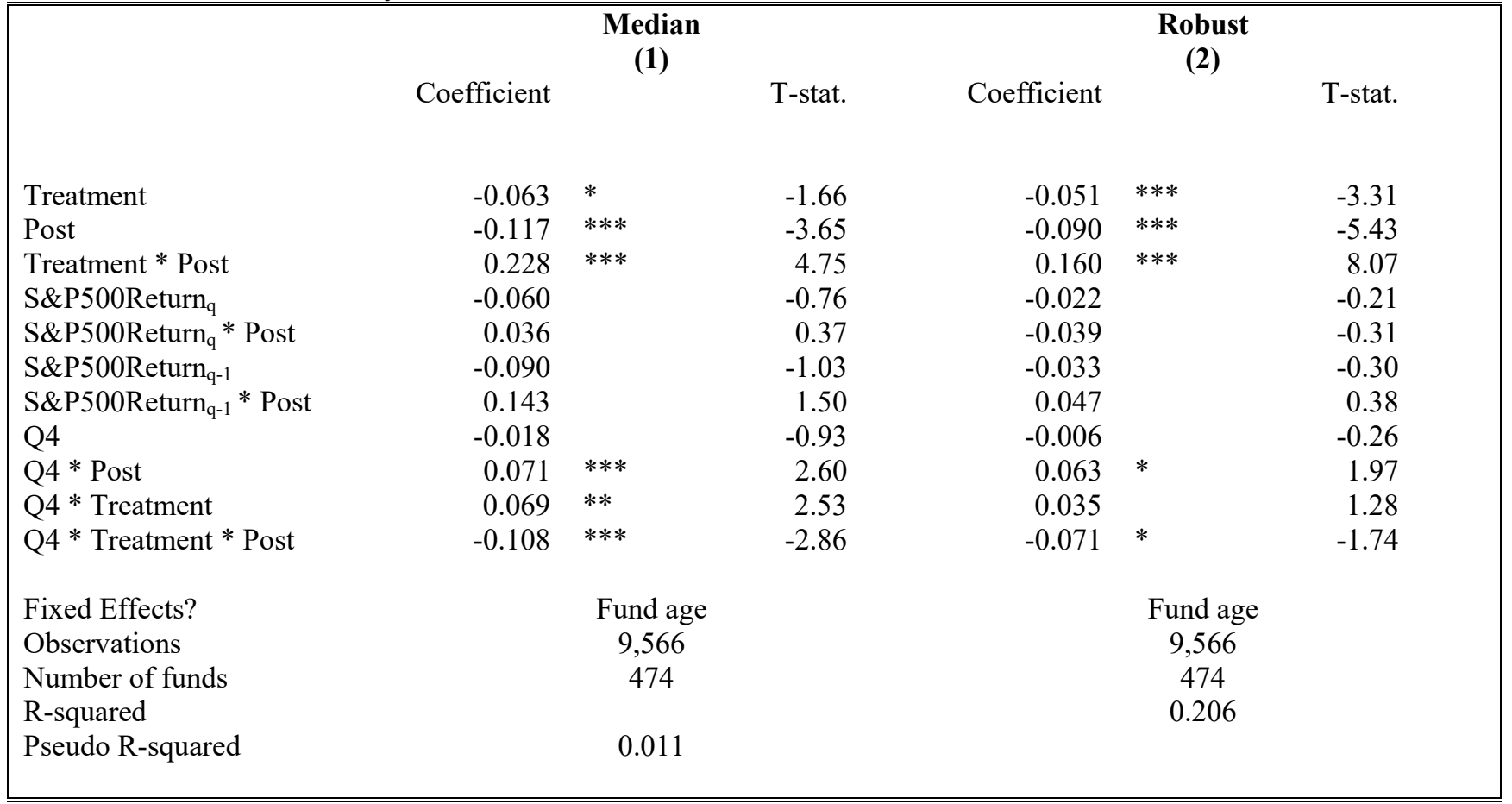

Panel B: NAV bias

\begin{tabular}{|c|c|c|c|c|c|c|}
\hline & & Med & & & Ro & \\
\hline & Coefficient & & T-stat. & Coefficient & & T-stat. \\
\hline Treatment & -0.013 & & -0.31 & -0.033 & & -1.36 \\
\hline Post & -0.041 & & -1.08 & -0.016 & & -0.61 \\
\hline Treatment $*$ Post & 0.051 & & 0.93 & 0.035 & & 1.12 \\
\hline S\&P500Return ${ }_{q}$ & -0.092 & & -1.05 & -0.095 & & -0.57 \\
\hline S\&P500Return $*$ Post & -0.126 & & -1.21 & -0.227 & & -1.16 \\
\hline S\&P500Return ${ }_{\mathrm{q}-1}$ & -0.017 & & -0.18 & -0.067 & & -0.38 \\
\hline S\&P500Return ${ }_{\mathrm{q}-1} *$ Post & -0.045 & & -0.41 & -0.017 & & -0.09 \\
\hline Q4 & 0.100 & $* * *$ & 4.41 & 0.103 & $* * *$ & 2.93 \\
\hline Q4 * Post & -0.091 & $* *$ & -2.92 & -0.110 & $* *$ & -2.19 \\
\hline Q4 $*$ Treatment & -0.051 & $*$ & -1.74 & -0.032 & & -0.76 \\
\hline Q4 $*$ Treatment $*$ Post & 0.058 & & 1.52 & 0.054 & & 0.86 \\
\hline Fixed Effects? & & Func & & & Fun & \\
\hline Observations & & 9,5 & & & 9, & \\
\hline Number of funds & & 47 & & & 4 & \\
\hline R-squared & & & & & $0 .($ & \\
\hline Pseudo R-squared & & -0.2 & & & & \\
\hline
\end{tabular}

